\title{
VARLIK VE İNSAN
}

Kemalpaşazade Bağlamında Bir Tasavvurun Yeniden İnşası

Ömer Mahir Alper, Klasik Yayınları, İstanbul, 2010, 205 sayfa

Rukiye AYDOĞAN*

İnsan nedir? Niçin vardır? Nasıl bir varlığa sahiptir? Onun bütün bir kâinat içerisindeki yeri ve konumu nedir? Meselesi ilk çağ filozoflarından günümüze kadar tartışılan bir konu olarak gelmiştir. Var olması bakımından, insanın felsefi anlamda var olandan ve varlıktan bağımsız incelenmesi mümkün görünmemektedir. Hiçbir meselenin, varlık meselesi aydınlatılmadan çözülemeyeceğini vurgulayan yazarımız, her insan bir âlemdir ve âlem, "Allah'ı işaret eden"dir demek suretiyle insanı bilmeden Allah'ı bilmenin mümkün olmayacağını savunmaktadır. Yazarımız bu düşüncesinden hareketle Varlık ve İnsan, adlı eserinde ontolojik bir bütünlük içerisinde varlık ve insanın bağlantılarını ortaya koymaya çalışırken Kemalpaşazade'nin düşüncesi üzerinden hareket etmektedir. Eserde insan, modern dönemlerde kendini gösteren parçacı ve indirgeyici yönelimin aksine ontolojik bir bütünlük içerisinde ele alınmaktadır.

Eser, önsözle girişten sonra yedi bölüm, sonuç, kaynakça ve dizinden oluşmaktadır.

Yazar kitabın içeriğini hazırlarken bölümlerdeki konu sıralamalarını oldukça başarılı bir şekilde yapmıştır. Konunun iyice kavranabilmesi açısından bir kavram ve varlık konusuyla başlayarak Tanrı konusu, âlem, insan ve insanın varlığa gelişi, insanın diğer varlıklardan üstünlüğü meselesi ve son olarak ölüm ve sonrası ile bitirmiştir.

Birinci bölüm, Varlık: Kavram ve Gerçeklik, (s.21-41) konusuna ayrılmıştır. $\mathrm{Bu}$ bölümde kavram çeşitleri, temel kavramın ne olduğu, niçin bütün kavramların temel kavram olarak kabul edilemeyeceği belirtilerek, varlık kavramının en temel kavram olma nedeni açıklanmıştır. Kemalpaşazade'ye göre varlık kavramı en temel kavramdır; çünkü tüm bilgilerimiz varlık kavramına dayanılarak oluşturulmaktadır. Bir kavramın zihnimizde bilfiil oluşması varlık kavramına bağlıdır. Bir kavram olarak varlık, tüm kavramların temeli iken bir gerçeklik olarak varlık da tüm var olanların temelidir. Ayrıca bu bölümde varlıklar, Zorunlu (vacib), olurlu (mümkün) ve imkânsız (mümte-

* SAÜ, Sosyal Bilimler, Felsefe ve Din Bilimleri,İslam Felsefesi, ABD Yüksek Lisans Öğrencisi, (rukiyeaydogan85@hotmail.com). 
ni) olmak üzere gruplandırılmıştır. İmkânsız; var olması mümkün olmayan, zorunlu; var olmaması imkânsız olan, yokluğu düşünülemeyen, olurlu; var olması veya var olmaması imkânsız/zorunlu olmayan biçiminde tanımlanmıştır. Kemalpaşazade'nin varlıkları gruplandırarak okuyucuyu ulaştırmak istediği noktalar vardır. Bu noktalardan biri; mümkünün mahiyetini varlık yönünde belirleyen, yani onun varlık kazanmasını sağlayan sebep nedir? Kemalpaşazade bu sorunun cevabını verirken okuyucuya mümkünün imkâna gelmesinin fail bir sebebe yani zorunlu varlık olan Tanrı'ya bağlı olduğunu göstermektedir.

İkinci bölüm Varlığın Ontolojik Temeli: Tanrı, (s. 43-70) konusuna ayrılmıştır. İnsanın hiçbir şeyin varlığından haberdar olmasa da kendi varlığının farkında olması varlığın var olduğunu göstermektedir. Var olandan hareketle, varlığa getiren fail sebebin bulunma süreci anlatılarak zorunlu varlığın özelliklerinden bahsedilmektedir. Kemalpaşazade'nin farklı eserlerinden örnekler verilerek konunun anlaşılması kolaylaştırılmaktadır. Ayrıca İbn Sina gibi felsefecilerden de örneklere yer verilmektedir. Bu bölümde konuyla ilgili felsefî, kelâmî ve tasavvufî kanıtlamaların her birine değinilerek okuyucu tatmin edilmeye çalışılmaktadır.

Üçüncü bölüm Tanrı'dan Başka Herşey: Âlem , (s.71-90) konusuna ayrılmıştır. Bu bölümde âlemin Tanrı'nın sıfatlarının bir tezahürü olarak incelendiğini görmekteyiz. Tanrı ile âlem arasında tek yönlü bir ilişki yerine, yaratıcı bir Tanrı'dan âleme doğru giden ve âlemden Tanrı'ya doğru giden bir ilişkinin var olduğu gösterilmektedir. Özellikle insanın önemi ön plana çıkartılarak, insanın küçük âlem olarak Tanrı'nın en büyük kanıtı olduğu gösterilmektedir. Ayrıca Kemalpaşazade'nin âlemin ezeli olup olmadığı hususunda kelamcılarla farklı düşündüğü noktalar da belirtilerek açıllanmaktadır.

Dördüncü bölüm Âlemler İçre Bir Âlem ya da Tanrı 'nın En Büyük Delili: Insan ( s. 91-107) konusuna ayrılmıştır. Bu bölümde âlemlerin çeşitleri sıralanarak tanımları yapılır. Kemalpaşazade: "Âlemin anlamı ve değeri, insanın varoluşunda gizlidir"'(sy. 105)der ve İnsanı bilmenin, Tanrı'yı bilmek olduğu söylenerek, götüreceğini söyleyerek, insanın diğer varlıklar içinde konumunun özel olduğunu açıklar. Kemalpaşazade insanın var oluşunu, “insanı kâmil" olarak adlandırılan fikir üzerine bina etmektedir. İnsan-1 kâmil olarak adlandırılan bu fikrin İbnu'l-Arabi'nin hakikat-i Muhammediyye fikrine yakın bir tarzda olduğu da görülmektedir. Kemalpaşazade insânî ruhu, Tanrı'nın kudretinin ilk taalluk ettiği şey olarak tasvir etmektedir. Daha sonra Kemalpaşazade insanın yapısını anlatmaya geçmektedir. İnsanın üç boyutunu aşağıdan yukarıya doğru yükselen hiyerarşik bir sıralama ile göstermektedir: beden (kesif ceset)-ruh (latif cisim)-nefs (arınık cevher). Kemalpa- 
şazade insanı, zahiri ve batıni yönlere ayırarak, beden ruh ilişkisini açıklamaktadır.

Beşinci bölüm, İnsanın Varlı̆̆a Gelişi ve Asli Yapısı: Varoluşun İnkişafı, (s. 109-134)konusuna ayrılmıştır. Bu bölümde Kemalpaşazade tarafından özellikle insanın metafizik ya da ruhani boyutuyla, evrenin ortaya çıkmasından önce var olduğu görüşü vurgulanarak, İnsan dışındaki varlıkların insan için var kılındığ anlatmaya geçmektedir. Ona göre insan önce nefs, sonra ruh, sonra da cisminin yaratılmasıyla mürekkep bir varlık olarak dünyada mevcut olmuştur. Burada yazar tarafından, dikkatleri çeken bir ayrımın olduğu vurgulanmaktadır: İbn Sina gibi filozofların aksine Kemalpaşazade nefsin ruhtan önce var olduğunu söylemektedir.

Altıncı bölüm, Varlık Mertebeleri ve Insan: Niçin Insan Meleklerden de Üstündür? (s.135-151) Bu bölümde mevcudiyet ya da aydınlatıcılık yönü esas alınarak bir varlık hiyerarşisi sunulmuştur. Mevcudiyet yönü esas alınarak yapılan varlık mertebelerinde zatı ile varlığı aynı olan mevcud, Tanrı ilk sırada; varlığı zatından başka olan mevcud, yani Tanrı dışındaki her şey ikinci sırada yer almaktadır. Aydınlatıcılık yönü esas alınarak yapılan varlık mertebelerinde cisimsel âlemin aydınlatıcıları; en büyükten aşağıya doğru güneş, ay, yıldızlar ve ateştir. Ruhani âlemin aydınlatıcıları ise Tanrı, ruh-i azam, meleklerin derecesi ve insani ruhtur. Görüldüğü gibi mevcudiyet ya da aydınlatıcılık yönü esas alınarak yapılan varlık hiyerarşisinin en üstünde Tanrı yer almaktadır. Bu sıralama sonucunda insan, meleklerden üstün müdür, değil midir? Sorusu gündeme gelmiştir. Kemalpaşazade ruhu ve bedeni ile bir bütün olan insanın meleklerden nasıl üstün sayılabileceğini kendinden önceki belirli düşünürlerin görüşlerini özetleyerek vermektedir. Konuyla ilgili tartışmaların ayetler üzerinden yapılarak devam ettirildiği görülmektedir. Kemalpaşazade insanın, melekten daha üstün olduğunu ifade derken insanların cisimlerinin kesif, meleklerin cisimlerinin latif olduklarına dikkatleri çekerek, kesif cisme sahip olan insanın meşakkatinin fazlalığı sebebiyle latif cisimden daha üstün olduğunu vurgulamaktadır. Ayrıca Kemalpaşazade varlıksal yapı derecelendirmesinde bazı meleklerin insanlardan üstün olabildiğine de değinerek, bazı hevasına uyan insanlarında hayvanlardan daha aşağıda olabileceğini ifade etmektedir

Yedinci bölüm, Ölüm ve Sonrası: Yeniden Varoluş, (s. 153-178)konusuna ayrılmıştır. Hayat gibi ölümünde Allah tarafından var kılındığı ifade edilerek ölümün bir gerçeklik olup âlemde yer alması gerektiği belirtilmektedir. Ölümün mutlak bir yokluk değil, bir halden başka bir hale intikal olduğu, ölüme doğru giden her ferdin aslında yetkinleşmeye doğru gittiği ifade 
edilmektedir. Asıl önemli olanın iradi ölümle ulaşılan kemal olduğunu vurgulayan Kemalpaşazade, insanın erdem çizgisinde durmasını sağlayacak üç yetkinliğinden bahseder. Bunlar arzu gücü, öfke gücü ve düşünme gücüdür. İnsan bu üç güce ait erdemleri hakkıyla yaparsa mutluluğa erişecektir.

Kemalpaşazade cismani haşr ile ilgili kendisinden önce öne sürülen görüşlere iktibasta bulunmaktadır. Cismani haşrin tüm fertler için değil mükellef fertler için geçerli olduğunu savunur. Ayrıca yaratılacak bedenlerin dünyadaki bedenlerin aynıları olup olmayacağını tartışmaktadır. Bu konuda önemli olan şeyin ruhların mutlak bir bedene sahip olmaları meselesi olduğunu, yoksa dünyadaki bedenle aynısı olmasının çok da önemli olmadı̆̆ını belirtmektedir.

Sonuç bölümünde (s.179-186), insanın anlamının bütüncül varlık düzeninde ele alınmasının gerekliliği ve önemi üzerinde durularak Tanrı'dan bağımsız bir insan tasavvurunun niçin yapılamayacağı açıklanmaktadır.

Yazarın böyle bir eser yazma amacı; insanı incelemek, onun varlığına ilişkin temel meselelere kapsamlı bir açıklama getirmektir. Bu çalışmanın temel iddialarından biri olan insanın anlamının, ancak varlığın anlamının kavranmasıyla anlaşılabileceği, özellikle İslam geleneği içerisinde ortaya çıkmaktadır. İslam düşüncesinin önemli bir kısmını teşkil eden Osmanlı geleneğinde ise bu konuya yoğun ilgi gösterenlerden biri Kemalpaşazade olduğu için eser onun düşüncesi üzerinden gerçekleştirilmiştir.

Esere genel olarak bakıldığında, öz olarak insanın mebde ve meadıyla birlikte bir bütün halinde incelenmeye çalışıldığı görülmektedir. İnsanı beden ve ruhtan ibaret gören indirgemeci yaklaşımlara sunulan itirazların ve cevapların tatmin edici seviyede olduğu görülmektedir. Gerek kitabımızın yazarı Ömer Mahir Alper gerekse Kemalpaşazade konuyla ilgili öne sürdükleri ifadelerin nerelere dayandığını okuyucuya göstermişlerdir. Kendi görüşlerine muhalif olan görüşleri de ifade etmekten çekinmemişlerdir.

Kemalpaşazade'nin hemen hemen bütün eserlerinde belirli bir konuyu ele alırken kendinden önceki pek çok düşünür ve bilginin görüş ve tespitlerine doğrudan yer verdiği ve onların eserlerinden alıntılar yaptığı görülmektedir. Kemalpaşazade'nin bu tutumu, kendinden öncekilerin düşüncelerine sıkı sıkıya bağlı olduğu izlenimini vermiş olsa da, o bu tutumuyla ya kendi görüşlerini temellendirmek ya da belirli görüş ve fikirlerle bir hesaplaşma içine girmek istediğini göstermektedir. Kemalpaşazade'nin hakikati her şeyin üstünde tutarak bütün akım ve disiplinlerden istifade edip başarılı bir senteze ulaşmış olduğu görülmektedir. Kelam, felsefe ve tasavvuf geleneklerini birbirine karşı konumlandırmak yerine yaklaştırmak amacını güttügüunü eserin bütününe baktığımızda rahatlıkla görmekteyiz. İnsanın hem felsefe- 
nin, hem kelamin hem de tasavvufun konusu olması, eserde ifade edilen görüşler, eserin kıymetini artırmıştır.

Eserdeki zengin aktarıma bakarak, eserin kelam, tasavvuf ve felsefeye ilgi duyanlara katkı sağlayacağını söyleyebiliriz. 